\title{
Bronchial gland dimensions in coalminers: influence of smoking and dust exposure
}

\author{
AN DOUGLAS, D LAMB, VA RUCKLEY \\ From the Institute of Occupational Medicine, Edinburgh
}

ABSTRACT Bronchi from 94 coalminers were examined for enlargement of the mucous glands. The measurements used were the mean and maximum ratios of gland thickness to wall thickness, the mean acinar diameter, and the ratio of the gland area to the area of the non-cartilaginous portion of the bronchial wall. The relationships between these measurements and the subjects' smoking habits and their past $ᄋ$ exposure to dust in the coal mines were analysed. Smoking was found to be significantly related to mean and maximum gland-to-wall ratios. In addition, coalmine dust exposure was found to be significantly related to $\bigcirc$ maximum gland:wall ratio. No significant relationships were found between gland dimensions and $\frac{0}{\circ}$ pneumoconiosis or dust retained in the lung. These results lend support to the view that irritants encountered $\stackrel{\Phi}{-}$ in an occupational environment may play an important part in the development of hypersecretion of mucus.

Measurement of the dimensions of the bronchial mucous gland was pioneered by Reid, ${ }^{1}$ who found that the proportion of mucous glands in the bronchial wall was increased in patients with chronic bronchitis. Subsequent work has indicated that this association between enlargement of mucous glands and bronchitis is less clearcut than was initially suggested. The relation between chronic bronchitis and smoking is well known and smoking has been shown to be associated with enlargement of the bronchial glands. ${ }^{2-5}$

Rae $e t a l^{6}$ showed for the first time an increase in the prevalence of bronchitis among a group of coalface workers as their cumulative exposure to respirable dust increased. Studying gold miners, Wiles and Faure ${ }^{7}$ found a relation between the dust inhaled and both chronic bronchitis and airways obstruction.

In a necropsy study of lungs from Australian coalminers, Leigh $e t a^{8}$ found no association between the proportion of mucous glands in the bronchial wall and either smoking or time spent in various working environments. Other studies on coalminers have not been concerned with the role of occupational factors in the development of gland enlargement. Ryder et al ${ }^{9}$ examined differences between miners with and without radiographic signs of coalworkers' pneumoconiosis and found none, while Glick et $a l^{10}$ showed that gland enlargement was related to clinical symptoms of bronchitis in a mining population but took the analysis no further.

The aim of the present work was to elucidate the relation

Address for reprint requests: Dr D Lamb, Pathology Branch, Institute of Occupational Medicine. 8 Roxburgh Place, Edinburgh EH8 9SU. between exposure to coalmine dust and mucous gland enlargement.

\section{Methods}

We examined the bronchi from 94 deceased coalworkers. $\overrightarrow{\vec{O}}$ This group was selected, from 500 men included in a 3 necropsy study of coalworkers' lungs, ${ }^{11} 12$ on the basis of a consistently reported smoking history. The main source? of material was the pneumoconiosis medical panels of the Department of Health and Social Security. The men had all participated during life in the National Coal Board's $x$ pneumoconiosis field research, the objectives and research methods of which are well documented. ${ }^{13} 14$

Smoking histories were obtained from the pneumoconiosis medical panels' notes. Cases were excluded if the reported smoking habits had varied over the years; for 3 non-smokers in particular we adhered rigorously to this $\frac{7}{0}$ principle of consistency. The cases were divided into four groups according to smoking habit, as follows: non- N smokers, ex-smokers (five years or more), light smokers ( $\leqslant 10$ cigarettes/day), and medium and heavy smokers (> 10 cigarettes/day) (table 1 ). As only two men had admitted to smoking more than 20 a day, we did not have $a$ ? category of heavy smokers. Although the minerso examined do not represent a true cross-section of British coalworkers they do cover the range of pulmonary:diseases associated with coalmining.

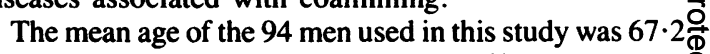
years, $80 \%$ of them having been over 60 .

From the measurements of dust concentration and $\stackrel{\mathbb{Q}}{\varrho}$ relevant manpower records collected during the pneumo? 
Table 1 Numbers of men in each smoking group

\begin{tabular}{lll}
\hline Smoking group & No of men & Codefor group \\
\hline Non-smokers & 17 & 0 \\
Ex-smokers & 23 & 1 \\
Current smoker, & 29 & 2 \\
$\quad \begin{array}{l}\quad 10 \text { cigarettes/day } \\
\text { Current smoker. }\end{array} \quad 25$ cigarettes/day & 25 & 3 \\
\hline
\end{tabular}

coniosis field research we calculated the cumulative exposure to coalmine dust for each man. We included only exposure to "respirable" dust, as described by Hamilton and Walton; ${ }^{15}$ a method for calculating this has been described. ${ }^{14}{ }^{16}$ Cumulative dust exposure is expressed as gram-hours per cubic metre of sampled air $\left(\mathrm{gh} / \mathrm{m}^{3}\right)$.

Measurements of the lung dust content were made routinely on the 500 men included in the necropsy studies of coalworkers' lungs. ${ }^{11} 12$ A description of the extraction and analysis of lung dust is given by Davis et al. ${ }^{17}$ The amount of dust retained in the lungs was expressed $(a)$ as the total weight of dust retained by the lung and $(b)$ as the weight of dust in $100 \mathrm{~g}$ of blood-free, dust-free tissue.

The lungs from the 94 miners were examined for evidence of coalworkers' pneumoconiosis. Three broad groups (M, F, and PMF) were defined on morphological grounds from naked-eye observations. ${ }^{12}$ The M (macule) group comprised lungs with dust deposits, but no macroscopic evidence of fibrosis. Radiographs in these cases rarely showed evidence of pneumoconiosis. Lungs in the $\mathrm{F}$ or fibrotic-nodule group had one or more "nodules" with a solid, palpable centre of at least $1 \mathrm{~mm}$ but less than $10 \mathrm{~mm}$ in diameter. If the lungs contained one or more fibrotic lesions $10 \mathrm{~mm}$ or more in diameter the case was assigned to the progressive massive fibrosis (PMF) group.

HISTOLOGICAL EXAMINATION OF BRONCHI Where possible, blocks were taken from the following six sites in the upper bronchial tree for histological examination: left and right main bronchi, left and right upper lobe bronchi, left lower lobe bronchus, and right bronchus intermedius.

In all, 496 sections of bronchi were examined, of which 209 were complete cuffs. Histological sections were cut at $8 \mu \mathrm{m}$, stained for elastic by Weigart's method, and counterstained for muscle and collagen by van Gieson's method. The following measurements were made (the first two on all 496 sections and the others where complete cuffs of bronchi were available):

(1) Ratio of gland thickness to wall thickness. This was measured according to the method of Reid. ' Up to six measurements were made at positions where the epithelial basement membrane ran roughy parallel to the underlying cartilage. Two values of the ratio were used in the analyses -a mean value and a maximum value calculated as the mean of the highest ratios recorded at each site.
(2) Mean diameter of glandular acini. These were measured at an objective magnification of 40 diameters. A maximum of 12 readings per section were taken. The largest acini were measured as advocated by De Haller and Reid. ${ }^{18}$ Where the section under examination was a complete circumference of bronchial wall or nearly so, then three acini were measured in each of the four quadrants of the cuff. If the section was incomplete it was scanned from one end to the other, the largest 12 acini being measured on the traverse.

(3) Gland area.

(4) Cartilage area, cartilage being judged to extend to the inner aspect of the perichondrium.

(5) Total bronchial wall area. The bronchial wall was delineated by the mucosal basement membrane of the luminal surface and by the obvious junction between connective tissue associated with the bronchus and the surrounding tissue.

Measurements 1-3 were made with the aid of a drawing tube attachment to the microscope, which enabled the image of a pen to be seen on the histological section. The appropriate lengths and areas were recorded on paper and subsequently measured.

Measurements of cartilage area and total bronchial wall area were performed on tracings taken from the projected image of the bronchus. The areas were computed with a point count grid.

The gland area was expressed as a percentage of the total wall area less cartilage:

$$
\text { Gland index }=\frac{\text { gland area } \times 100}{\text { total wall area }- \text { cartilage area }} .
$$

ANALYSIS OF DATA

The method of analysis used to investigate the relationships was linear regression. The first models fitted had three exponent variables. The first two variables, smoking group and dust exposure, remained the same and the third was changed. Smoking group and dust exposure were not associated with each other $(r=0.04)$. The third variable was either total weight of lung dust, weight of dust in $100 \mathrm{~g}$ of blood-free and dust-free tissue, age, or pathological group. Age was included as it could be argued that any effect supposedly due to dust exposure or lung dust content might simply be accounted for by age. Pathological group was included as Davis et al ${ }^{11}$ showed that the total weight of dust retained in the lung increased through the pneumoconiosis groups $(\mathrm{M} \rightarrow \mathrm{F} \rightarrow \mathrm{PMF})$. Thus any relationship with lung dust might also hold good for the pathological group. For these analyse's ex-smokers were excluded as the models did not accommodate changes in smoking habit.

From table 2 dust exposure is seen to be strongly correlated with total lung dust and lung dust in $100 \mathrm{~g}$ of tissue and the two expressions of lung dust to be highly correlated with each other. For this reason these variables 
Table 2 Correlation coefficients between explanatory variables

\begin{tabular}{|c|c|c|c|c|c|}
\hline & $\begin{array}{l}\text { Smoking } \\
\text { group }\end{array}$ & $\begin{array}{l}\text { Total } \\
\text { lung } \\
\text { dust }\end{array}$ & $\begin{array}{l}\text { Lung dust } \\
\text { in } 100 \mathrm{~g} \\
\text { tissue }\end{array}$ & Age & $\begin{array}{l}\text { Patho- } \\
\text { logical } \\
\text { group }\end{array}$ \\
\hline Exposure & -0.03 & $0.47 *$ & $0 \cdot 40 *$ & 0.09 & $0 \cdot 17$ \\
\hline Smoking group & $1 \cdot 00$ & $-0 \cdot 13$ & $-0 \cdot 15$ & 0.08 & $-0 \cdot 16$ \\
\hline Total lung dust & & $1 \cdot 00$ & 0.85 & $0 \cdot 19$ & $0 \cdot 38$ \\
\hline
\end{tabular}

${ }^{*} \mathrm{p}<0.01$.

were tested separately when we were looking for associations between them and the measures of bronchial wall dimension.

\section{Results}

The coefficients of the regression equations are shown in tables 3 and 4 . Smoking was found to be significantly associated with both mean and maximum gland:wall thickness ratios and gland acinus diameter $(\mathrm{p}<0.05$, $0.01,0.01$ respectively). Dust exposure was significantly associated $(\mathrm{p}<0.05)$ with maximum gland:wall ratio and age with acinar diameter. Gland index was not associated with any of the explanatory variables. We could not show

Table 3 Values for the components of the regression equations: mean and maximum gland:wall ratios $(G W R)$, mean acinar diameter (mean $A D$ ), and gland index versus smoking group. dust exposure, pathological group, and age (number of cases $7 I$. ex-smokers excluded)

(a) Pathological group included as a variable

\begin{tabular}{|c|c|c|c|c|c|}
\hline \multirow{2}{*}{$\begin{array}{l}\text { Bronchial } \\
\text { measurement }\end{array}$} & \multicolumn{5}{|c|}{ Regression coefficients } \\
\hline & Constant & $\begin{array}{l}\text { Smoking } \\
\text { group }\end{array}$ & $\begin{array}{l}\text { Dust } \\
\text { exposure }\end{array}$ & $\begin{array}{l}\text { Patho- } \\
\text { logical } \\
\text { group }\end{array}$ & $r$ \\
\hline $\begin{array}{l}\text { Mean GWR } \\
\text { Max GWR } \\
\text { Mean AD } \\
\text { Gland index. } \$\end{array}$ & $\begin{array}{l}34 \cdot 84 \\
39 \cdot 52 \\
54 \cdot 67 \\
20 \cdot 95\end{array}$ & $\begin{array}{l}1 \cdot 53 \doteqdot \\
2 \cdot 10 \doteqdot \\
2 \cdot 62 \doteqdot \\
0 \cdot 17\end{array}$ & $\begin{array}{l}0.0077 \\
0.0135^{\dagger} \\
0 \cdot 0043 \\
0 \cdot 0058\end{array}$ & $\begin{array}{r}0 \cdot 63 \\
1 \cdot 21 \\
1 \cdot 00 \\
-0.92\end{array}$ & $\begin{array}{l}0 \cdot 33+ \\
0 \cdot 41 \div \\
0 \cdot 46 \div \\
0 \cdot 15\end{array}$ \\
\hline
\end{tabular}

(b) Age included as a variable

\begin{tabular}{|c|c|c|c|c|c|}
\hline \multirow{2}{*}{$\begin{array}{l}\text { Bronchial } \\
\text { measurement }\end{array}$} & \multicolumn{5}{|c|}{ Regression coefficients } \\
\hline & Constant & $\begin{array}{l}\text { Smoking } \\
\text { logical }\end{array}$ & $\begin{array}{l}\text { Dust } \\
\text { exposure }\end{array}$ & Age & $r$ \\
\hline Mean G & & $1.49 \div$ & 0.0079 & 0.03 & $0 \cdot 32 \doteqdot$ \\
\hline Max GWR & 38. & $2 \cdot 01 \div$ & $0.0140^{\dagger}$ & 0.06 & $0.40 \div$ \\
\hline Mean AD & $42 \cdot 18$ & $2 \cdot 46 \div$ & 0.0037 & $0.23 \div$ & $0.50 \div$ \\
\hline Gland index $\S$ & $26 \cdot 86$ & $0 \cdot 21$ & $0 \cdot 0058$ & $0 \cdot 10$ & 0.17 \\
\hline
\end{tabular}

(c) Only two variables included

\begin{tabular}{|c|c|c|c|c|}
\hline \multirow{2}{*}{$\begin{array}{l}\text { Bronchial } \\
\text { measurement }\end{array}$} & \multicolumn{4}{|c|}{ Regression coefficients } \\
\hline & Constant & $\begin{array}{l}\text { Smoking } \\
\text { group }\end{array}$ & $\begin{array}{l}\text { Dust } \\
\text { exposure }\end{array}$ & $r$ \\
\hline Mean GWR & $36 \cdot 26$ & $1 \cdot 50 \div$ & $0 \cdot 0080$ & $0 \cdot 32 \doteqdot$ \\
\hline Max GWR & $42 \cdot 23$ & $2 \cdot 03 \div$ & $0.0143 \div$ & $0 \cdot 40$ \\
\hline Mean AD & $56 \cdot 92$ & $2 \cdot 57 \div$ & 0.0048 & $0 \cdot 45 \div$ \\
\hline Gland index $\S$ & $18 \cdot 92$ & 0.25 & 0.0050 & $0 \cdot 11$ \\
\hline
\end{tabular}

Table 4 Values for the components of the regression equations: mean and maximum gland:wall ratios (GWR) and gland index versus smoking group, total lung dust, and dust in $100 \mathrm{~g}$ of blood-free, dust-free tissue (number of cases 71 , ex-smokers excluded)

(a) Total lung dust included as a variable

\begin{tabular}{lllll}
\hline $\begin{array}{l}\text { Bronchial } \\
\text { measurement }\end{array}$ & $\begin{array}{l}\text { Regression coefficients } \\
\text { Constant }\end{array}$ & $\begin{array}{l}\text { Smoking } \\
\text { group }\end{array}$ & $\begin{array}{l}\text { Total } \\
\text { lung dust }\end{array}$ \\
\hline Mean GWR & $38 \cdot 2 \dagger$ & $1 \cdot 45 \dagger$ & $0 \cdot 03$ & $0 \cdot 28 \div$ \\
Maximum GWR & $46 \cdot 0$ & $2 \cdot 06 \doteqdot$ & $0 \cdot 03$ & $0 \cdot 33 \doteqdot$ \\
Gland index \& & $19 \cdot 2$ & $0 \cdot 37$ & $0 \cdot 05$ & $0 \cdot 12$ \\
\hline
\end{tabular}

(b) Lung dust in $100 \mathrm{~g}$ of tissue included as a variable

\begin{tabular}{|c|c|c|c|c|}
\hline \multirow{2}{*}{$\begin{array}{l}\text { Bronchial } \\
\text { measurement }\end{array}$} & \multicolumn{4}{|c|}{ Regression coefficients } \\
\hline & Constant & $\begin{array}{l}\text { Smoking } \\
\text { group }\end{array}$ & $\begin{array}{l}\text { Lung dust in } \\
\text { loog of tissue }\end{array}$ & $r$ \\
\hline Mean GWR & $38 \cdot 2$ & $1.46 \div$ & $0 \cdot 04$ & $0.28 \div$ \\
\hline Maximum GWR & $46 \cdot 4$ & $2 \cdot 05 \div$ & 0.01 & $0.33 \stackrel{\leftarrow}{\leftarrow}$ \\
\hline Gland index § & $18 \cdot 7$ & 0.42 & $0 \cdot 11$ & $0 \cdot 16$ \\
\hline
\end{tabular}

$\dagger \mathrm{p}<0.05$.

$\neq \mathrm{p}<0 \cdot 01$

$\S$ Measured on complete sections only—6I cases included.

any difference between smoking groups in their associations between the anatomical measurements and dust exposure. Simple linear regression analysis showed no association between measurements performed on the major bronchi and the coal, ash, and quartz components of the lung dust content.

Average values for the maximum gland:wall ratio for cases divided by smoking group and levels of dust exposure are shown in table 5 . The values were generally higher in the smoking groups than the non-smokers. In the light smokers the values were higher for those with higher dust exposures and the difference between highexposure and low-exposure groups nears significance at conventional levels $(\mathrm{p}=0.051)$.

The results indicate that: (a) smoking contributes significantly to the enlargement of glands as measured by the mean and maximum gland:wall ratios and to the enlargement of the tubules (acini) of the glands; $(b)$ dust exposure contributes to the enlargement of mucous glands as measured by maximum gland:wall ratio; (c) dust retained in the lung (total or percentage of tissue), age, and pneumoconiosis (pathological) group are not associated with overall dimensions of the mucous gland dimensions; $(d)$ gland area as a percentage of noncartilaginous wall area is not significantly related to dust exposure or smoking.

\section{Discussion}

Previous studies have found an association between enlargement of bronchial glands and smoking ${ }^{245}$ and in this respect the present study does not differ. The association between the maximum ratio of gland thickness to wall thickness and coalmine dust exposure is, so 
Table 5 Average values of maximum gland:wall ratio for cases divided by smoking group and dust exposure (numbers in parentheses indicate cases in subgroup)

\begin{tabular}{|c|c|c|c|c|}
\hline \multirow[t]{2}{*}{ Smoking group } & \multicolumn{3}{|c|}{ Dust exposure $\left(\mathrm{gh} / \mathrm{m}^{3 *}\right)$} & \multirow{2}{*}{$\begin{array}{l}\text { All } \\
\text { exposures }\end{array}$} \\
\hline & $<200$ & $200<400$ & $\geqslant 400$ & \\
\hline $\begin{array}{l}\text { Non-smokers } \\
\text { SD }\end{array}$ & $\begin{array}{l}45 \cdot 2(5) \\
4 \cdot 0\end{array}$ & $\begin{array}{l}45 \cdot 9(9) \\
(8 \cdot 8)\end{array}$ & $\begin{array}{l}48 \cdot 1(3) \\
15 \cdot 0\end{array}$ & $\begin{array}{l}46 \cdot 1(17) \\
8 \cdot 5\end{array}$ \\
\hline $\begin{array}{l}\text { ( } \leqslant 10 \text { cigarettes/day) } \\
\text { SD } \\
\text { Smokers }\end{array}$ & $\begin{array}{c}48 \cdot 0(8) \\
7.9\end{array}$ & $\begin{array}{c}50 \cdot 1(17) \\
6 \cdot 8\end{array}$ & $\begin{array}{c}56 \cdot 6(4) \\
4 \cdot 0\end{array}$ & $\begin{array}{l}50 \cdot 4(29) \\
7 \cdot 1\end{array}$ \\
\hline $\begin{array}{l}\text { (>10 cigarettes/day) } \\
\text { SD } \\
\text { Ex-smokers } \\
\text { SD }\end{array}$ & $\begin{array}{c}50 \cdot 4(7) \\
9 \cdot 3 \\
46 \cdot 3(8) \\
6 \cdot 4\end{array}$ & $\begin{array}{l}52 \cdot 6(16) \\
5 \cdot 2 \\
48 \cdot 5(12) \\
8 \cdot 2\end{array}$ & $\begin{array}{l}52 \cdot 7(2) \\
1 \cdot 4 \\
42 \cdot 4(3) \\
5 \cdot 3\end{array}$ & $\begin{array}{l}52 \cdot 0(25) \\
6 \cdot 3 \\
46 \cdot 9(23) \\
7 \cdot 3\end{array}$ \\
\hline $\begin{array}{l}\text { All cases } \\
\text { SD }\end{array}$ & $\begin{array}{c}47 \cdot 6(28) \\
7 \cdot 2\end{array}$ & $\begin{array}{l}49 \cdot 8(54) \\
7 \cdot 2\end{array}$ & $\begin{array}{c}50 \cdot 3(12) \\
9 \cdot 2\end{array}$ & $\begin{array}{c}49 \cdot 2(94) \\
7 \cdot 5\end{array}$ \\
\hline
\end{tabular}

*Gram-hours per cubic metre of sampled air.

far as we are aware, a new observation. It is a result that supports the idea that irritants encountered in an industrial environment may be important in the development of chronic hypersecretory bronchitis, as suggested by several epidemiological studies. ${ }^{6}{ }^{19-21}$

The lack of association with the other indices of gland enlargement may be explained by the fact that for most of the people examined in the study exposure to coalmine dust had ended more than five years before death and for one-third 10 or more years before. These men could be regarded as ex-dust-breathers. The number of men still in employment at the time of death was 24 and this group was considered too small to analyse the results separately.

There is, however, some experimental evidence suggesting that the bronchial mucous glands revert to their original size after the stimulus to secrete is removed. In work where the stimulus was of an acute nature the gland enlargement seemed to be due to the swelling of the mucous cells by their secretions. ${ }^{22}$ In chronic bronchitis the mucous gland enlargement is largely due to an increase in cell numbers ${ }^{23}$ and what happens to the glands after the removal of an irritant is unknown, though some diminution in volume is likely. The lack of association between the area gland index and smoking and dust exposure may in part be due to a reduction in gland volume after regular inhalation of dust ceased. By contrast, the association between the maximum gland: wall ratio and these factors may be due to some residual, localised gland enlargement. These findings are otherwise difficult to explain. If sufficient data from men who were still employed at the collieries at their time of death can be collected then it will be interesting to compare them with those from the current study.

A second limitation may be that for only 44 of the men were there measured exposure data covering $20 \%$ or more of their working life, their previous exposure having been estimated. ${ }^{14}$ Exposure measurements for the pneumoconiosis field research did not start until the mid 1950s, by which time the men in the study had been working for an average of 30 years. Earlier exposure data were not available for the study group but the exposure levels were likely to have been higher as dust suppression was not widespread before $1952 .{ }^{24}$

A further factor may be that the data on dust exposure we used are a measure of the "respirable" dust. This is only a fraction of the dust to which a man has been exposed as it excludes particles greater than $7 \cdot 1 \mu \mathrm{m}$ diameter and half of those over $5 \mu \mathrm{m}$. Most of the larger particles are removed from the air by the mouth or nose, the rest being deposited in the trachea and large bronchi. Animal experiments have shown that, in addition to local irritation, mucus secretion from the tracheobronchial glands can be stimulated by irritation of the nasopharynx. ${ }^{25}$ If this is the case in man then a stronger relationship may exist between "bronchitis" and the fraction of airborne dust that is inhaled and subsequently impinges on the upper airways.

No relationships between mucous gland dimensions and lung dust or pneumoconiosis could be shown. With regard to pneumoconiosis, the present results are in accordance with those of Ryder et al. ${ }^{9}$ As lung dust content and pneumoconiosis are likely to be related to respirable dust exposure and mucous gland enlargement to inhalable dust the lack of association is not unexpected.

Although other studies have found that the overall dimensions of the bronchial glands tend to be enlarged in elderly people ${ }^{2627}$ no such effect was noted in this study. The apparent inconsistency between the association of age with the diameter of the larger acini and the absence of such an association with the proportion of gland in the bronchial wall is explained by the observation that gland enlargement is due to the proliferation of the gland tubules and not to increase in the size of those already present. ${ }^{23}$ Acinar diameter and the ratio between gland thickness and wall thickness (or gland index) are therefore measurements of different aspects of the bronchial mucous glands.

As the work reported here has been concerned only with the large bronchi, we can make little comment on the idea that "industrial" bronchitis is confined to the upper airways, as suggested by Morgan. ${ }^{28}$ It does, however, support the view that irritants encountered in an occupational environment do play an important part in producing hypersecretion in the proximal bronchi.

This work formed part of a thesis accepted for the degree of M Phil by the University of Edinburgh. We are grateful to Mr JS Chapman and Mr H Tully and their colleagues for help with the work, and to Mrs Paula Collings for stastistical guidance. We acknowledge gratefully the financial support of the National Coal Board and the Commission of the European Communities. 


\section{References}

' Reid L. Measurement of the bronchial mucous gland layer: a diagnostic yardstick in chronic bronchitis. Thorax 1960;15:132-41.

2 Thurlbeck WM, Angus GE, Pare JAP. Mucous gland hypertrophy in chronic bronchitis and its occurrence in smokers. Br J Dis Chest 1963;57:73-8.

3 Thurlbeck WM, Angus GE. A distribution curve for chronic bronchitis. Thorax 1964;19:436-42.

${ }^{4}$ Field WEH, Davey EN, Reid L, Roe FJC. Bronchial mucous gland hypertrophy: its relation to symptoms and environment. Br J Dis Chest 1966;60:66-80.

5 Megahed GE, Senna GA, Eissa MH, Saleh SZ, Eissa HA. Smoking versus infection as the aetiology of bronchial mucous gland hypertrophy in chronic bronchitis. Thorax 1967;22:271-8.

${ }^{6}$ Rae S, Walker DD, Attfield M. Chronic bronchitis and dust exposure in British coal miners. In: Walton WH, ed. Inhaled particles III. Vol 2. Old Woking, Surrey: Unwin Bros, 1971:883-94.

${ }^{7}$ Wiles FJ, Faure MH. Chronic obstructive lung disease in gold miners. In: Walton WH, ed. Inhaled particles IV. Oxford: Pergamon Press, 1977:727-34.

${ }^{8}$ Leigh J, Outhred KG, McKenzie HJ, Wiles AN. Multivariate analysis of quantified aetiological, clinical and post-mortem pathological variables related to respiratory disease in coal-miners. In: Walton WH, ed. Inhaled particles $V$. Oxford: Pergamon Press (in press).

${ }^{9}$ Ryder RC, Lyons JP, Campbell H, Gough J. Bronchial mucous gland status in coal workers pneumoconiosis. Ann N Y Acad Sci 1972;200:370-80.

${ }^{10}$ Glick M, Outhred KG, McKenzie HJ. Pneumoconiosis and respiratory disorders of coal mine workers in New South Wales, Australia. Ann N Y Acad Sci 1972;200:316-34.

1 Davis JMG, Chapman J, Collings P, et al. Autopsy studies of coalminers' lungs (final report on CEC contract 6244-00/8/ 103). Edinburgh: Institute of Occupational Medicine, 1979. (IOM Report TM/79/9.)

12 Ruckley VA, Chapman JS, Collings PL, Douglas AN, Fernie JM, Lamb D, Davis JMG. Autopsy studies of coalminers' lungs - phase II (final report on CEC contract 7246-15/8/ 001). Edinburgh: Institute of Occupational Medicine, 1981. (IOM Report TM/81/18.)

${ }^{13}$ Fay JWJ. The National Coal Board's pneumoconiosis field research. Nature 1957;180:309-10.
${ }^{14}$ Fay JWJ, Rae S. The pneumoconiosis field research of the National Coal Board. Ann Occup Hyg 1958/59;1:149-61

15 Hamilton RJ, Walton WH. The selective sampling of respirable dust. In: Davies $\mathrm{CN}$, ed. Inhaled particles and vapours. Oxford: Pergamon Press, 1961:465-81.

${ }^{16}$ Hurley JF, Copland L, Dodgson J, Jacobsen M. Simple pneumoconiosis and exposure to respirable dust: relationships from twenty-five years' research at ten British coal mines. Edinburgh: Institute of Occupational Medicine, 1979. (IOM Report TM/79/13.)

${ }^{17}$ Davis JMG, Ottery J, Le Roux A. The effect of quartz and other non-coal dusts in coalworkers' pneumoconiosis. Part II. Lung autopsy study. In: Walton WH, ed. Inhaled particles IV. Oxford: Pergamon Press, 1977:691-700.

${ }^{18}$ De Haller R, Reid L. Adult chronic bronchitis. Medicina Thoracalis 1965:22:549-67.

${ }^{19}$ Higgins ITT, Cochrane AL. Chronic respiratory disease in a random sample of men and women in the Rhondda Fach in 1958. Br J Ind Med 1961;18:93-102.

${ }^{20}$ Sluis-Cremer GK, Walters LG, Sichel HS. Chronic bronchitis in miners and non-miners: an epidemiological survey of a community in the gold mining area in the Transvaal. $\mathrm{Br} \mathrm{J}$ Ind Med 1967;24:1-12.

${ }^{21}$ Rogan JM, Attfield MD, Jacobsen M, Rae S. Walker DD. Walton WH. Role of dust in the working environment in development of chronic bronchitis in British coal miners. $\mathrm{Br}$ $J$ Ind Med 1973;30:217-26

${ }^{22}$ Baskerville A. The development and persistence of bronchial gland hypertrophy and goblet-cell hyperplasia in the pig after injection of isoprenaline. J Pathol 1976;119:35-47.

${ }^{2.3}$ Douglas AN. Quantitative study of bronchial mucous gland enlargement. Thorax 1980;35:198-201.

${ }^{24}$ Jones CO. A comparison of airborne dust concentrations in the South Wales coalfield in the period 1943-1975. Mining Engineer 1979;138:847-59.

25 Phipps RJ, Richardson PS. The effects of irritation at various levels of the airway upon tracheal mucous secretion in the cat. J Physiol 1976;261:563-81.

${ }^{26}$ Hernandez JA, Anderson AG, Holmes WL, Morrone N. Foraker AG. The bronchial glands in aging. $J$ Am Geriat Soc 1965;13:799-804.

${ }^{27}$ Bedrossian CWM, Anderson AE, Foraker AG. Comparison of methods for quantitating bronchial morphology. Thorax 1971;26:406-8.

${ }^{28}$ Morgan WKC. Industrial bronchitis. $\mathrm{Br} J$ Ind Med 1978;35:285-91. 
strong state. It is not therefore satisfactory to use a gentler technique for its removal.

P RAJ BEHL A HEDLEY BROWN Department of Cardiothoracic Surgery Regional Cardiothoracic Centre Freeman Hospital Newcastle upon Tyne

${ }^{1}$ Reyes LH, Ratzan KR, Rheinlander HF. Serratia marcescens bacteraemia originating from a catheter line in the left atrium after mitral valve replacement. J Thorac Cardiovasc Surg 1973;65:241-4.

${ }^{2}$ Bricker DL, Dalton ML. Cardiac tamponade following dislodgement of a left atrial catheter following coronary artery bypass. J Thorac Cardiovasc Surg 1973;66:636-8.

${ }^{3}$ Browdie SA, Agnew RF, Hamilton CS jun. Poppet-jamming during mitral valve replacement [letter]. Ann Thorac Surg 1978;28:591.

\section{Notices}

\section{Annual meeting of the European Academy of Allergology and Clinical Immunology}

The annual meeting of the European Academy of Allergology and Clinical Immunology 1984 will be held in Brussels on 16-19 May. The themes will be the immunological aspects of asthma, occupational allergy, and immunomodulation, with a postgraduate course on the treatment of allergic diseases. Further information from Professor $\mathbf{R}$ Pauwels, Department of Respiratory Diseases, De Pintelaan 185, B 9000 Ghent, Belgium.

\section{Applied respiratory physiology}

A course in applied respiratory physiology will be held at the Royal Postgraduate Medical School, Hammersmith Hospital, from 26 to 30 March 1984. The topics will include mass spectrometry, body plethysmography, noninvasive monitoring, nocturnal hypoxaemia, control of breathing, regional lung function, airflow obstruction, diffusion and clinical pulmonary function testing. Visiting speakers will include Dr NR Anthonison (Canada). Application forms and further details are available from: School Office (SSC), Royal Postgraduate Medical School, Hammersmith Hospital, London W12 0HS.

\section{Ninth International Cystic Fibrosis Congress}

The medical/scientific programme of the Ninth International Cystic Fibrosis Congress will be held in Brighton from 12 to 15 June 1984. Papers on any aspect of cystic fibrosis may be submitted (closing date for abstracts 31 January 1984). The principal plenary sessions will include presentations on: prenatal diagnosis and carrier detection, pathophysiology (characteristics of the cystic fibrosis cell, calcium metabolism, glycoproteins of cystic fibrosis mucus), the changing management of cystic fibrosis (aerosol antibiotics, the role of exercise, supplemental nutrition), and the basic defect. There will be an allied health professionals programme that will include parallel sessions on social aspects of cystic fibrosis, dietetics and nutrition, and physiotherapy. Further details are obtainable from the Congress Office, Cystic Fibrosis Research Trust, Alexandra House, 5 Blyth Road, Bromley, Kent BR1 3RS.

\section{Corrections}

\section{Bronchial gland dimensions in coalminers: influence of smoling and dust exposure}

Drs Douglas, Lamb and Ruckley in their paper (Thorax $1982 ; 37: 760-4)$ refer to work by Dr WKC Morgan and colleagues ( $\mathrm{Br} J$ Ind $\mathrm{Med}$ 1978;35:285-91). It has become clear that Dr Morgan's work has been misquoted: Dr Morgan did not state that industrial bronchitis is confined to the upper airways. The authors regret this error.

\section{Microbiological investigation of farmer's lung disease in Somerset 1963-83}

In the abstract by JP Anderson and FB Greatorex (September 1983, p 709), "acute" in the 6th line from the end should be "chronic"- that is, "In chronic farmer's lung disease. ..." 